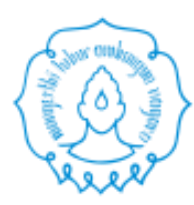

\author{
UNIVERSITAS SEBELAS MARET \\ BIOEDUKASI: JURNAL PENDIDIKAN BIOLOGI \\ https://jurnal.uns.ac.id/bioedukasi/ \\ 1693-265X (Print)| 2549-0605 (Online)
}

\title{
Students' Learning Outcomes and Activities: The Use of Video Conference during COVID-19 Pandemic
}

\author{
Mutiara Arieny a, 1, Mgs. Muhammad Tibrani a, 2,* , Didi Jaya Santri a, 3 \\ a Biology Education, Sriwijaya University, Palembang-Indonesia \\ ${ }^{1}$ mutiaraarieny@gmail.com ; ${ }^{2}$ m_tibrani@fkip.unsri.ac.id*; ${ }^{3}$ dj_santri@fkip.unsri.ac.id \\ * Corresponding author
}

\begin{tabular}{ll}
\hline Submission & $: 29 / 07 / 2021$ \\
Revision & $: 07 / 08 / 2021$ \\
Accepted & $: 31 / 08 / 2021$
\end{tabular}

\section{ABSTRACT}

This research was motivated by problems during the covid-19 pandemic, it showed that the students' activity and learning outcomes of the topic of Ecosystem at Public High School 10 Palembang remain low. Based on observations of the electronic learning process carried out at the school, the teacher mostly applies asynchronous learning, thus the interactivity between teacher and students is not performed well. This study aimed to find out the effect of using video conferencing on the topic of Ecosystem toward the activities and learning outcomes of students. This study was set up as a quasiexperiment, using a nonequivalent control group design with two groups. The experimental group (Grade 10 of MIA 2) which do e-learning using video conference and the control group (Grade 10 of MIA 4) where e-learning without using video conference. Both groups were selected randomly. Data collection instruments were learning activity observation sheets and biology learning outcomes tests. Learning activity was analyzed quantitatively, while the learning outcomes data were also run quantitatively on a prerequisite test, hypothesis testing and the N-gain test. The results show the average percentage of experimental class learning activities increased from $39.5 \%$ to $42.5 \%$ while the control class did not increase. The Ancova test showed a significance value of 0.000 or less than $=0.05$ and the N-gain test was 0.36. Based on the results, the use of video conferencing on the topic of Ecosystem significantly affected the learning outcomes improvement.

This is an open-access article under the CC-BY-SA license
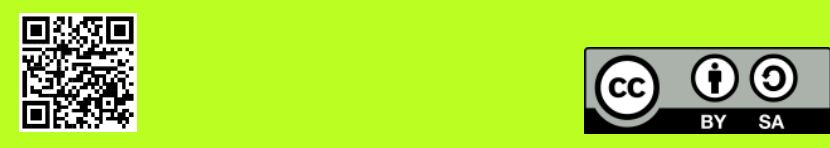

Keywords: E-learning, Learning Activities, Learning Outcomes, Video Conferencing 
Aryeni, et al. | Students' Learning Outcomes and Activities.....

\section{Introduction}

Coronavirus Disease (COVID-19) has become a trending topic of conversation around the world. The Ministry of Education and Culture gave instructions to conduct distance learning for schools and universities by spreading a Decree No. 36962/MPK.A/HK/2020 (Kementerian Pendidikan dan Kebudayaan RI, 2020). Education in the industrial era 4.0 can ward off education that is feared to be hampered during this pandemic. The industrial revolution 4.0 era requires people to be able to adapt to the existing challenges and changes, especially in using information technology to support the success of distance learning. This demand requires schools to be able to implement electronic learning optimally. Thus, students are expected to be able to better understand concepts in the field of science, which is biology. However, the facts based on several studies show that the activities and learning outcomes of students are still less than the minimum criteria.

Learning activities are activities of students who use ideas, intelligence, and interest in the learning process to develop cognitive, norms, affective, and psychomotor (Nurmala et al., 2014; Rosiana et al., 2012). A good learning activity is when students process and respond to the information conveyed by the teacher actively (Anggreiny et al., 2020). Therefore, good learning activities can result in cognitive and psychomotor formation leading to improved learning outcomes.

Based on the results of initial observations carried out with class $X$ biology teachers at SMAN 10 Palembang, she stated that during the Covid-19 pandemic biology learning activities were carried out using asynchronous learning assisted by the Google Classroom platform. The method that educators use is by sending materials, media, and assignments to be studied and done by students. Meanwhile, educators use links from Google Forms that are distributed to students through Google Classroom to learn evaluation. The results of learning activities at SMAN 10 Palembang on biology learning show the percentage of learning activity scores that are less than optimal. During the learning process on ecosystem materials, students also quickly feel bored and indifferent when e-learning. It will prevent students from having a good understanding and can affect their learning outcomes.

Learning outcomes are the outputs of students' learning activities in terms of cognitive, affective, and psychomotor aspects which are measured through assessment/evaluation. Learning outcomes are very important for the process of determining the success of the implementation of learning. Student learning outcomes show the cognitive aspects that students have regarding learning materials (Mitrayani et al., 2018).

Initial observation of e-learning during Covid-19 pandemic shows that the achievement of learning outcomes in ecosystem material is relatively low. One class at SMAN 10 Palembang, Grade 10 of MIA 2, with 40 students, there were only 7 students who completed the minimum completeness criteria on ecosystem materials, so the classical completeness reached $18 \%$. Ecosystem material is too hard to learn because students do not understand and connect it with daily life. One of the parts that are considered hard to understand by students is the material cycle (Çimer, 2012). The material cycle is part of an ecosystem that learns about biogeochemical cycles and energy flow consisting of concept materials. They compared fact and principal materials that make it difficult for students to understand ecosystem materials. This problem will have an impact on learning outcomes obtained by students. The low learning outcomes indicate that the learning that educators apply has not been fully successful and research needs to be done.

Electronic learning (e-learning) is the use of various electronic media to carry out educational or learning activities that can be used anytime and anywhere, so as to solve the problems of space and time in learning (Aryaningrum, 2016; Haske \& Wulan, 2015). The use of e-learning helps us to save time, to reduce tuition fees, to cover a wider area, and to educate students acquiring knowledge more independently. However, electronic learning does not 
provide a clear picture of the information conveyed because of the low interactivity between educators and students in asynchronous learning (Yazdi, 2012). Early models of asynchronous learning were not effective because the system lacked student-teacher interaction as well as student-to-student interaction. it may lead to misinterpretation of other people's ideas. On the other hand, in synchronous learning the teacher and the students could interact with each other at a given time and place. The advantage of utilizing synchronous learning is that it facilitates real time collaboration, the student and the teacher may interact spontaneously, and the participants can have immediate feedback from each other (Lim, 2017; Shahabadi \& Uplane, 2015). Therefore, the solution to this problem is the implementation of synchronous learning using video conferencing.

Video conferencing is an example of synchronous learning. The main benefit of synchronous learning is that it allows students to get rid of feelings of isolation because they can interact with educators or other students during learning activities. Video conferencing is an interactive telecommunications technology tool that is used to interact and conduct learning through audio and video simultaneously by students and educators in distance learning (Sandiwarno, 2016; Silitonga \& V, 2012). So, through video conferencing, it is expected to be able to make learning fun, increase the element of interactivity and improve student learning outcomes. Therefore, to overcome these problems, synchronous learning is applied using video conferencing. This study aimed to find out the effect of using video conferencing on the activities and learning outcomes of students in class $\mathrm{X}$ ecosystem material.

\section{Methods}

This research took place at SMAN 10 Palembang which was held from October 2020 to July 2021. This study used a quantitative approach with the Quasi-experimental method. The method used is the nonequivalent control group design where the researcher will divide the students into two groups, namely the control group and the experimental group. The following table shows the research design used:

Table 1. Nonequivalent Control Group Design Pattern

\begin{tabular}{cccc}
\hline Group & Pretest & Treatment & Posttest \\
\hline Control & $\mathrm{O} 1$ & $\mathrm{~T} 1$ & $\mathrm{O} 2$ \\
Experimental & $\mathrm{O} 3$ & $\mathrm{~T} 2$ & $\mathrm{O} 4$ \\
\hline
\end{tabular}

Note:

$\mathrm{T}_{1}$ : Control group treatment (without using video conference)

$\mathrm{T}_{2}$ : Experimental group treatment (using video conference)

$\mathrm{O}_{1}$ : pretest score control group

$\mathrm{O}_{2}$ : posttest score control group

$\mathrm{O}_{3}$ : pretest score experimental group

$\mathrm{O}_{4}$ : posttest score experimental group

The population in this study were students of class X MIA SMAN 10 Palembang. The sample in this study were students in class X MIA 2 as the experimental group and students in class X MIA 4 as the control group. Class X MIA 2 and X MIA 4 each consist of 20 students. The sample selection in this study was carried out using a simple random sampling technique.

In this study, data collection used test and non-test instruments. The test instrument is in the form of a cognitive test of biology learning outcomes, while the non-test instrument is a 
learning activity observation sheet. The learning outcomes measured are limited to cognitive biology learning outcomes in ecosystem materials. The biology learning outcomes test given is in the form of multiple-choice objective tests related to ecosystem materials totaling 20 questions that have validity and reliability requirements based on cognitive aspects including knowledge level (C1), understanding (C2), application (C3) and analysis (C4). Then, observations were made using an observation sheet containing indicators about student learning activities during the learning process. Observation of learning activities include visual activities; oral activities; writing activities; and mental activities. The indicators of visual activities are students reading the material that has been uploaded and paying attention to the teacher's explanation. The indicators of oral activities are students asking questions and expressing their opinions. The indicators of writing activities are students taking notes on the material or important points explained by the teacher, working on, and collecting the student's worksheet. The indicators of mental activities are students answering questions and concluding the material bravely.

Learning activity data is obtained from qualitative data in the form of observations about teaching and learning situations, namely for data from observations of student learning activities, it is calculated using the equation below (Aminoto \& Pathoni, 2014).

$$
A=\frac{N a}{N} \times 100 \%
$$

Note:

$$
\begin{array}{ll}
\mathrm{A} & =\text { Students' activities } \\
\mathrm{Na} & =\text { Number of active students } \\
\mathrm{N} & =\text { Number of all students }
\end{array}
$$
Table 2.

The interpretation of the value of student learning activities used the criteria shown in Table 2. Interpretation of Student Learning Activity Values

\begin{tabular}{cc} 
Range & Categories \\
\hline $81-100$ & Very active \\
$61-80$ & Active \\
$41-60$ & Quite Active \\
$21-40$ & Less Active \\
$0-20$ & Inactive \\
\hline
\end{tabular}

(Aminoto \& Pathoni, 2014)

While the data obtained from the results of the pre-test and post-test were analyzed to determine the increase in learning outcomes. Related to the analysis of learning outcomes data, a prerequisite test is carried out in the form of a homogeneity test and a normality test. Then proceed with hypothesis testing using the Analysis of Covariance (Ancova) test and the Ngain test. Ancova aimed to determine the effect of treatment on the dependent variable by controlling for other variables (Sudaryono, 2016). The hypothesis in this study is:

$\mathrm{H}_{0}$ : The use of video conferencing has no significant effect on improving the learning outcomes of students' ecosystem materials in class X SMAN 10 Palembang. 
H1: The use of video conferencing has a significant effect on improving the learning outcomes of students' ecosystem materials in class X SMAN 10 Palembang.

\section{Results And Discussion}

\section{Students' Learning Activities}

During the lesson, researchers taught ecosystem materials to the control class using the announcement feature in google classroom and the experimental class using video conferencing by utilizing the screen sharing feature in Zoom Cloud Meeting. Learning using video conferencing at Zoom Cloud Meeting is equipped with HD video features so that students and researchers can listen to the material more clearly. Researchers also take advantage of presentation features that help in explaining because we can point the cursor, write, and make highlights during presentations. Researchers also interact with students such as finding out the students' initial understanding, conducting questions and answers to providing learning reflections. In the control class, the researcher utilizes the comments and chat rooms in Google Classroom, while the experimental class uses the online synchronous zoom feature which allows educators and students to interact in real time. This feature is also equipped with clear audio, which can be turned on and off to make the class more conducive. Researcher also takes advantage of the task feature in Google Classroom to send assignments to the control class and experimental class.

The types of learning activities observed in the control class and experimental class include visual activities, oral activities, writing activities and mental activities. The percentage of student learning activity results for each type of learning activity can be seen in Figure 1 .

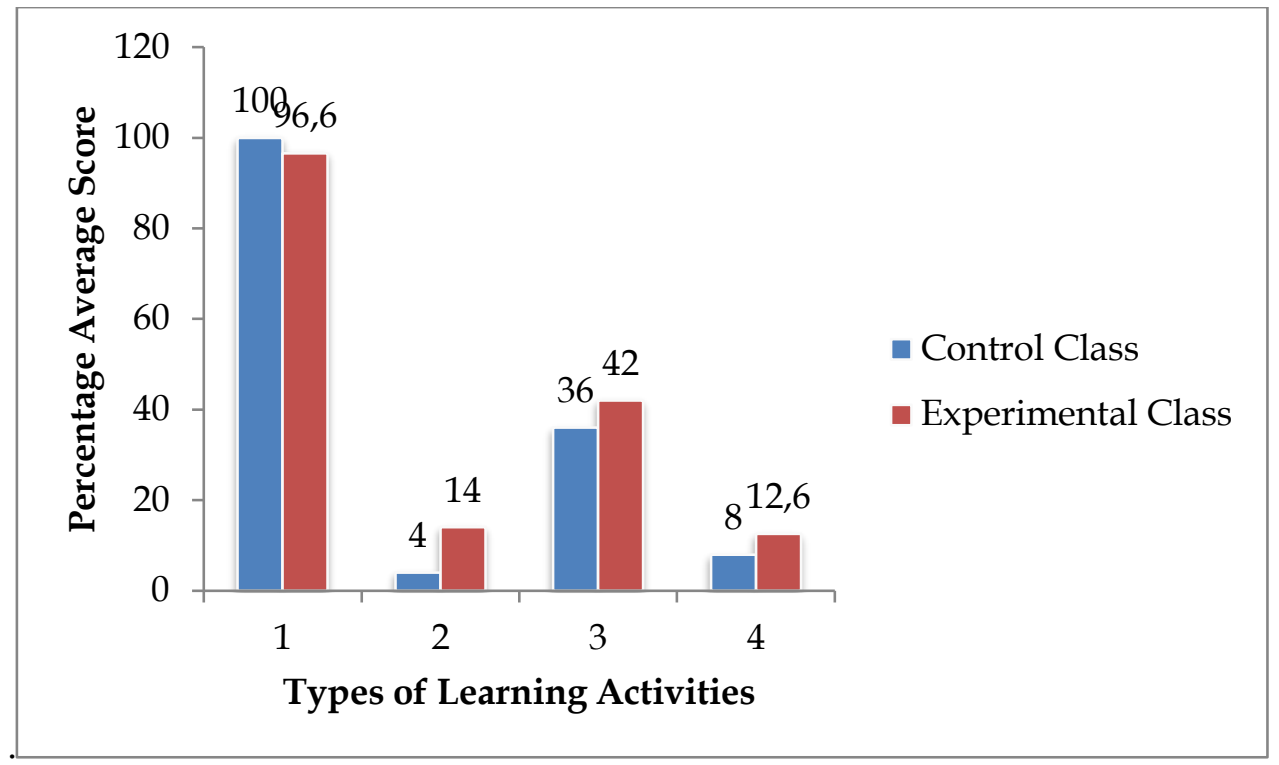

Figure 1. Results of Learning Activities Based on Their Types

Note:

1. Visual activities

2. Oral activities

3. Writing activities

4. Mental activities 
In Figure 1 the learning activities of students in the control class and the experimental class for the activity of paying attention are very active with an average score of $100 \%$ and $96.6 \%$. For oral activities, the results of the average percentage of students in the control class showed $4 \%$ which was categorized as inactive. Meanwhile, with an average percentage difference of $10 \%$, the results of the oral activity of students in the experimental class which showed $14 \%$ were also categorized as inactive. Then for writing activities, the results of the average percentage score of students in the control class showed 36\% which was categorized as less active. Meanwhile, for the experimental class, the percentage of writing activity was $42 \%$ with quite active category. Finally, the mental activity of students in the control class and the experimental class were both categorized as inactive with a difference in the average percentage score of $4.6 \%$ with details of mental activity in the control class at $8 \%$ and mental activity in the experimental class at $12.6 \%$.

The results of the data on student learning activities from both classes can be illustrated in graphical form. The comparison graph of the results of student learning activities at first, second and third meetings is shown in Figure 2.

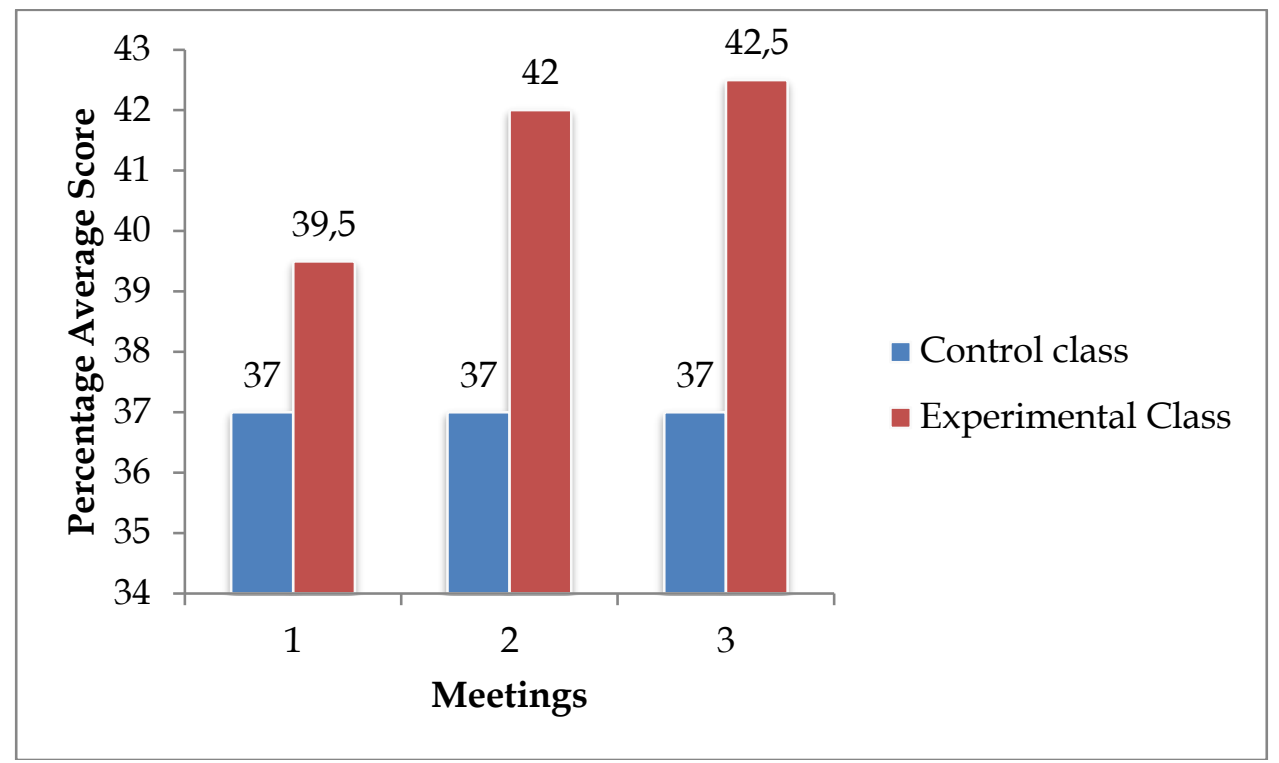

Figure 2. Results of Learning Activities First, Second and Third Meetings

Based on Figure 2 by utilizing the features of video conferencing for electronic learning, the results of the average percentage of student learning activities in the experimental class first meeting showed $39.5 \%$ in the less active category and increased $2 \%$ on second meeting to $42 \%$ in the quite active. Then on third meeting, there was an increase of $0.5 \%$ in learning activities of students in the experimental class, so it became $42.5 \%$ categorized as quite active. While the control class did not increase with an average percentage of learning activities in amount of $37 \%$ categorized as less active. Based on this explanation, it can be concluded that the learning activities of students in the experimental class using video conferencing is more active than the learning activities of students in the control class.

Through the observations of the two classes, it can be concluded that the use of video conferencing can increase learning activities. This is supported by the results of observations showing that the activities of students in the experimental class is more active, so that teaching and learning activities become more meaningful. Using video conference allows students and educators to interact or do learning through audio and video simultaneously (Fitriyani et al., 2020). Video conferencing is also able to make teaching and learning activities not boring and have a high element of interactivity. Meanwhile, the control class with educators did not 
provide a clear picture of the information conveyed because of the low interactivity of asynchronous learning. Students also tend to passively accept the material that has been shared and are not motivated to ask questions and express opinions when learning.

\section{Students' Learning Outcomes}

In this study, the initial conditions of the students' abilities were tested by distributing pretests and after the treatment were carried out followed by posttests in the control class (X MIA 4) and experimental class (X MIA 2) related to ecosystem material. The results of the students' pretest and posttest can be seen in Figure 3.

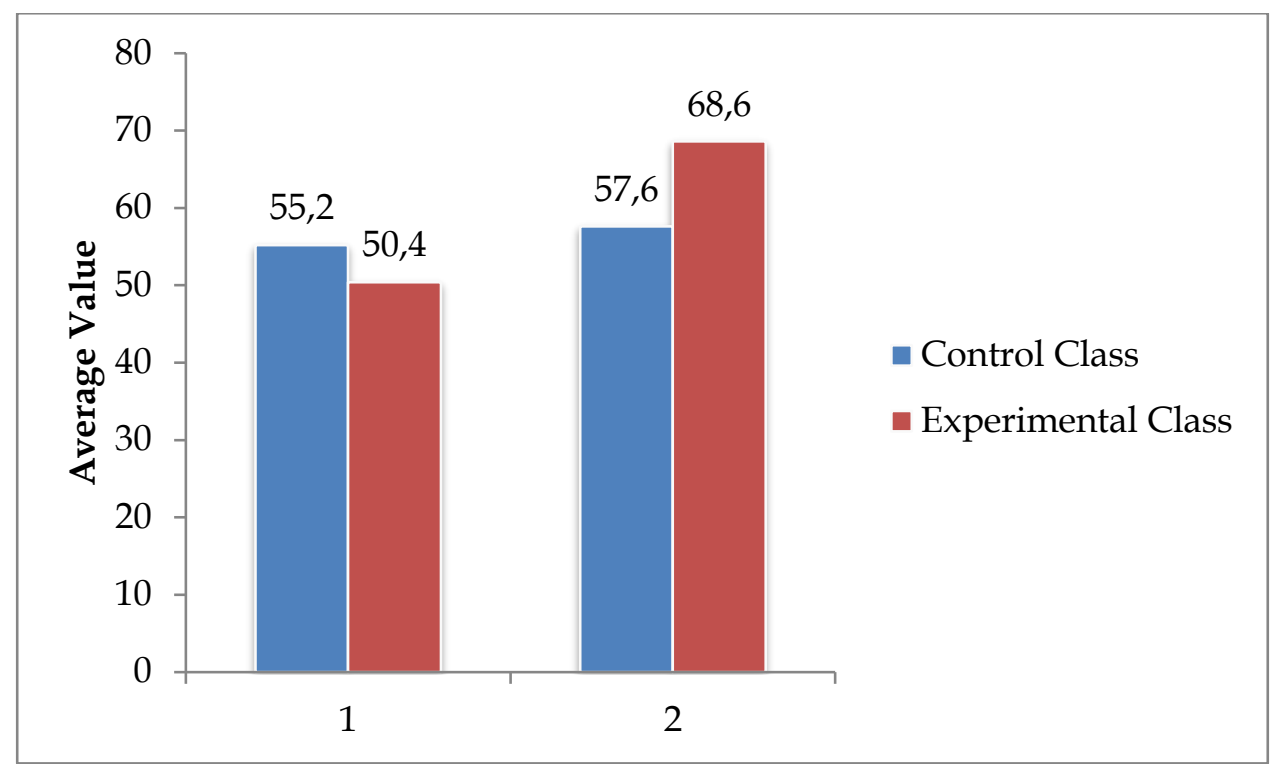

Note:

Figure 3. Learning Outcome Improvement Data

\section{Pretest}

2. Posttest

Based on Figure 3 shows the cognitive learning outcomes of students in the control class and the experimental class which is the pretest data in the control class reached an average of 55.2 and in the experimental class reached an average of 50.4. Then, there was an increase in learning outcomes of the control class and the experimental class. The results of the posttest data for the control class increased to 57.6, while the experimental class increased to 68.6. The following table 3 shows the Gain and N-gain values obtained in this study.

Table 3. Gain dan N-gain of Learning Outcome

\begin{tabular}{cccc}
\hline Class & Gain & N-gain & Description \\
\hline Control & 2,4 & 0,053 & Low \\
Experiment & 18,2 & 0,36 & Medium \\
\hline
\end{tabular}

According to Table 3 shows that the control class has a gain of 2.4 and an N-gain of 0.053 in the low category. Meanwhile, the experimental class has a gain of 18.2 and an $\mathrm{N}$-gain 
of 0.36 in the medium category. So, it can be concluded that the highest increase in learning outcomes is in the experimental class by conducting learning using video conferencing.

The prerequisite test results used the normality test and the homogeneity test. The normality test used is the Kolmogorov-Smirnov and Shapiro-Wilk. Calculation of normality test data using SPSS 20.0 can be seen in Table 4 .

Table 4. Normality Test Results

\begin{tabular}{cccccccc}
\hline & \multirow{2}{*}{ Class } & \multicolumn{2}{c}{ Kolmogorov-Smirnov ${ }^{\mathbf{y}}$} & \multicolumn{2}{c}{ Shapiro-Wilk } \\
\cline { 3 - 8 } & & Statistic & $\mathrm{df}$ & Sig. & Statistic & $\mathrm{df}$ & Sig. \\
\hline Learning & Pretest Experimental & .125 & 20 & $.200^{*}$ & .940 & 20 & .242 \\
Outcome & Posttest Experimental & .143 & 20 & $.200^{*}$ & .912 & 20 & .068 \\
& Pretest control & .145 & 20 & $.200^{*}$ & .939 & 20 & .232 \\
& Posttest control & .159 & 20 & $.200^{*}$ & .926 & 20 & .128
\end{tabular}

Based on the results of the normality test calculation using the SPSS application, the learning outcomes scores (pretest and posttest) in the control class and the experimental class have a P-value of the Lilliefors (Kosmogorov-Smirnov) normality test in amount to 0.2 which is greater than $=0.05$, so that the learning outcomes of the two classes come from a normally distributed population. Then the Shapiro-Wilk normality test also shows a P-value greater than $=0.05$, so that the learning outcomes of the two classes come from a normally distributed population.

Then proceed with the homogeneity test. The results of the homogeneity calculation using the Levene test are shown in Table 5.

Table 5. Variant Homogeneity Test Results

\begin{tabular}{lccccc}
\hline & Levene Statistic & df1 & df2 & Sig. & Decision \\
\hline $\begin{array}{l}\text { Learning } \\
\text { Outcome }\end{array}$ & .202 & 1 & 38 & .656 & Homogenous \\
\hline
\end{tabular}

Based on the calculation results, the homogeneity significance value is 0.656 , which means more than $=0.05$, so that the learning outcomes data come from a homogeneous population. From the results obtained, it can be determined that the learning outcomes of the control and experimental classes are homogeneous.

Analysis of research data used to test the hypothesis is using analysis of covariance (ANCOVA). Based on the results of the classical assumption test, it was determined that the data collected was homogeneous and normally distributed. So, for the hypothesis testing stage, analysis of covariance (ANCOVA) can be used. Calculation of data using SPSS 20.0 produces the results shown in Table 6. 
Table 6. Ancova Test Result

\begin{tabular}{cccc}
\hline Variable & Sig. & Description & P \\
\hline Corrected Model & 0.00 & Significant & 0.430 \\
Intercept & 0.00 & Significant & 0.462 \\
Class & 0.00 & Significant & 0.430 \\
\hline
\end{tabular}

The results of the Ancova test obtained a significance value of 0.000 which is less than $0,=0.05$, so the null hypothesis is rejected, and the alternative hypothesis is accepted, and it can be concluded if the use of video conferencing has a significant effect on improving student learning outcomes of ecosystem materials in class X SMAN 10 Palembang. Then the Partial eta squared value $\sqrt{0.430}=0.655$ which is greater than $=0.05$ indicating that there is no interaction between the pretest and posttest scores, so students are not affected by the pretest when doing the posttest.

The results of this study are in line with the research conducted by Ismawati and Prasetyo, the results of the research are learning using video conferencing in early childhood achieves a Gain of 10,313 and it is concluded that video conferencing has a significant effect on learning outcomes (Ismawati \& Prasetyo, 2020). This research is also in line with the research results obtained by Liu and Ilyas, namely that video conferencing also has a significant effect on the learning outcomes of students of physics education at the University of Flores. This statement is supported by the gain of 6.0741(Liu \& Ilyas, 2020). The research that conducted by Correia et all explained that video conferencing can be used as an effective teaching and communication tool in synchronous distance education. Moreover, due to the multimedia capabilities of web-based video conferencing technology, teachers and students can express themselves using audio, visual, and verbal communication with others. This reduces the ambiguity caused by text only communication and enhances psychological engagement, which potentially leads to a performance level in collaborative tasks comparable to face-to-face communication (Correia et al., 2020). According to studies, it can be concluded that learning using video conferencing has a significant effect on student learning outcomes.

Learning using video conferencing can improve learning outcomes higher than the control class because the online synchronous zoom feature on video conferencing allows educators to convey material and provide an overview of information to students through audio and video (Kusuma \& Hamidah, 2020) more clearly. Learning using video conferencing at Zoom Cloud Meeting is equipped with HD video features so that students and educators can listen to the material more clearly. Educators also take advantage of presentation features that help in explaining because educators can point the cursor, write to highlight when presenting. With learning using video conferencing, interactivity is higher because students and educators can interact and provide feedback directly and quickly, and educators can more easily manage classes, reach out and observe all students (Elyas, 2018). Communication using video conferencing between the educator and the students is visual, audio, and data based. The educator and the other students can hear the student who has been given the floor by the educator (Malik et al., 2017). With respect to data communication, the educator can present media such as PowerPoint to the students, ask them to answer the questions by pressing an appropriate button on the satellite phone, and immediately present the distribution of answers to the students. Learners may also need to ask questions to the instructor and/or share comments with the learning community because of their own reflections. Along the same lines, the chat feature, which is supported by all four systems and virtual hand-raising, which is only 
Aryeni, et al. | Students' Learning Outcomes and Activities.....

supported by Zoom Cloud Meeting, may be useful as well. Additionally, the annotation tools offered are useful to capture reflections and keep comments. (Correia et al., 2020).

\section{Conclusion}

According to the findings, it is shown that the use of video conferencing on ecosystem materials can improve student learning activities in class X SMAN 10 Palembang. Students' learning activities using video conferencing is $39.5 \%$ on first meeting, $42 \%$ on second meeting and $42.5 \%$ on third meeting, while in the control class is $37 \%$ and did not show an increase. Results of this research is also shown that the use of video conferencing has a significant effect on improving the learning outcomes of students' ecosystem materials in class X SMAN 10 Palembang. The use of video conferencing on ecosystem materials can improve student learning outcomes in class X SMAN 10 Palembang with an N-gain of 0.36 , while the control class is only improved learning outcomes with an N-gain of 0.053 . Future researchers should be able to conduct research using video conferencing on other learning materials and record the learning process.

\section{Acknowledgment}

Authors would thank to the Biology Education Study Program of Faculty of Teacher Training and Education, Sriwijaya University which has facilitated the research. Authors also thank to biology teachers and all participants of Public High School 10 Palembang for great assistance and cooperation.

\section{References}

Aminoto, T., \& Pathoni, H. (2014). Penerapan Media E-Learning Berbasis Schoology Untuk Meningkatkan Aktivitas dan Hasil Belajar Materi Usaha dan Energi di Kelas XI SMA N 10 Kota Jambi. Jurnal Sainmatika, 8(1), 13-29.

Anggreiny, G. I., Aseptianova, \& Nawawi, S. (2020). Analisis Aktivitas Belajar Siswa Kelas X pada Mata Pelajaran Biologi di SMA Negeri 10 Palembang. Jurnal Mangifera Edu, 4, 157-166. https://doi.org/10.31943/mangiferaeduv4i2.55

Aryaningrum, K. (2016). Pengaruh Pembelajaran Berbasis Web (E-learning) terhadap Hasil Belajar Siswa pada Mata Pelajaran Geografi Kelas XI di SMA Negeri 9 Palembang. Jurnal Media Penelitian Pendidikan, 10(2), 154-162. https:/ / doi.org/10.26877/mpp.v10i2.1517

Çimer, A. (2012). What Makes Biology Learning Difficult and Effective: Students' Views. Educational Research and Reviews, 7(3), 61-71. https://doi.org/10.5897/ERR11.205

Correia, A. P., Liu, C., \& Xu, F. (2020). Evaluating videoconferencing systems for the quality of the educational experience. Distance Education, 41(4), 429-452. https://doi.org/10.1080/01587919.2020.1821607

Elyas, A. H. (2018). Penggunaan Model Pembelajaran E-learning dalam Meningkatkan Kualitas Pembelajaran. Jurnal Warta, 56, 1-11. https://doi.org/10.46576/wdw.v0i56.4

Fitriyani, Febriyeni, M. D., \& Kamsi, N. (2020). Penggunaan Aplikasi Zoom Cloud Meeting pada Proses Pembelajaran Online Sebagai Solusi di Masa Pandemi COVID-19. Jurnal Edification, 3(1), 23-33. https://doi.org/10.37092/ej.v3i1.221

Haske, A. S., \& Wulan, A. R. (2015). Pengembangan E-learning berbasis Moodle dalam Pembelajaran Ekosistem untuk Meningkatkan Literasi Lingkungan Siswa pada Program Pengayaan. Seminar Nasional XII Pendidikan Biologi FKIP UNS 2015, 402-409.

Ismawati, D., \& Prasetyo, I. (2020). Efektivitas Pembelajaran Menggunakan Video Zoom Cloud Meeting pada Anak Usia Dini Era Pandemi Covid-19. Jurnal Obsesi: Jurnal Pendidikan Anak Usia Dini, 5(1), 665-675. https://doi.org/10.31004/obsesi.v5i1.671

Kementerian Pendidikan dan Kebudayaan RI. (2020). Surat Edaran No. 36962/MPK.A/HK/2020 (pp. 1-2). pp. 1-2. 
Kusuma, J. W., \& Hamidah. (2020). Platform Whatsapp Group dan Webinar Zoom dalam Pembelajaran Jarak Jauh pada Masa Pandemik COVID 19. Jurnal Ilmiah Pendidikan Matematika, 5(1), 97-106.

Lim, F. P. (2017). An Analysis of Synchronous and Asynchronous Communication Tools in e-Learning. Advanced Science and Technology Letters, 143(Ast), 230-234. https://doi.org/10.14257/astl.2017.143.46

Liu, A. N. A. M., \& Ilyas. (2020). Pengaruh Pembelajaran Online Berbasis Zoom Cloud Meeting terhadap Hasil Belajar Mahasiswa Fisika Universitas Flores. Jurnal Pendidikan Fisika Dan Keilmuan (JPFK), 6(1), 34-38. https:// doi.org/10.25273/jpfk.v6i1.7303

Malik, M., Fatima, G., Hussain Ch., A., \& Sarwar, A. (2017). E-learning: Students' perspectives about asynchronous and synchronous resources at higher education level. Bulletin of Education and Research, 39(2), 183-195. Retrieved from http://proxy.cityu.edu/login?url=https://searchproquest-com.proxy.cityu.edu/docview/1986751399?accountid=1230

Mitrayani, Hidayat, S., \& Novitasari, N. (2018). Pengaruh Model Pembelajaran Learning Cycle 7E terhadap Hasil Belajar Siswa pada Materi Keanekaragaman Hayati Kelas X MIA di SMA Negeri 10 Palembang. Jurnal Pendidikan Biologi, 9(1), 14-26. https://doi.org/10.24127/bioedukasi.v9i1.1378

Nurmala, D. A., Tripalupi, L. E., \& Suharsono, N. (2014). Pengaruh Motivasi Belajar dan Aktivitas Belajar terhadap Hasil Belajar Akuntansi. Jurnal Pendidikan Ekonomi Undiksha, 4(1), 1-10. https://doi.org/10.23887/jjpe.v4i1.3046

Rosiana, K. Y., Margiati, \& Halidjah, S. (2012). Peningkatan Aktivitas Belajar Siswa Menggunakan Metode Inkuiri Pada Pembelajaran Ilmu Pengetahuan Alam. Jurnal Pendidikan Dan Pembelajaran, 1(1), 1-10.

Sandiwarno, S. (2016). Perancangan Model E-learning Berbasis Collaborative Video Conference Learning Guna Mendapatkan Hasil Pembelajaran yang Efektif dan Efisien. Jurnal Ilmiah FIFO, 3(2), 191-200.

Shahabadi, M. M., \& Uplane, M. (2015). Synchronous and Asynchronous e-learning Styles and Academic Performance of e-learners. Procedia - Social and Behavioral Sciences, 176, 129-138. https:// doi.org/10.1016/j.sbspro.2015.01.453

Silitonga, Y., \& V, E. D. (2012). Analisa Perbandingan Kualitas Belajar-Mengajar antara Metode Face to Face dan Video Conference. Jurnal Sistem Informasi, 4(2), 477-487. https:// doi.org/10.36706/jsi.v4i2.1270

Sudaryono. (2016). Metode Penelitian Pendidikan (Edisi I). Jakarta: Kencana.

Yazdi, M. (2012). E-learning Sebagai Media Pembelajaran Interaktif Berbasis Teknologi Informasi. Jurnal Ilmah Foristek, 2(1), 143-152. 